\title{
NOTE
}

\section{MARKET POWER AND THE ANTITRUST LAWS: "NEW" OLD SECTION 7 OF THE CLAYTON ACT*}

Antitrust legislation is designed to maintain a competitive economy. ${ }^{1}$ While the success of this legislation in curtailing certain objectionable trade practices is generally recognized, ${ }^{2}$ its efficacy in curbing industrial concentra-

*United States v. E. I. Du Pont De Nemours and Co., 77 Sup. 'Ct. $\$ 72$ (1957).

1. See, e.g., Apex Hosiery Co. v. Leader, 310 U.S. 469 (1940) ; Paramount Famous Lasky Corp. v. United States, 282 U.S. 30 (1930).

Antitrust laws are designed to assure that the market, not the firm, determines the price and production levels of an industry. Thus, they are intended to prevent an individual firm from gaining the power to manipulate the market as it sees fit, and exact undue profit from the public. For competition is considered the system by which the price, terms and conditions of sale are best regulated. See, Handler, $A$ Study of the Construction and Enforcenent of the Federal Antitrust Laws, T.N.E.C. Mono. No. 38, 76th Cong., 3d Sess. (1941); Celler, Corporation Mergers and Antitrust Laws, 7 MERCER L. Rev. 267 (1956); Rostow, Monopoly Under the Sherman Act: Power or Purpose?, 43 ILL. L. REv. 745 (1949).

For a description of the competitive ideal, "pure" and "perfect" competition, see MACHlup, The Political Economy of Monopoly c. 1 (1952). But such a market system is merely an economic model; it posits a market in which the sellers and buyers are so small and so numerous that individually they can exert no influence. Clearly, it has no place in American business reality. When dealing with realities, economists talk in terms of "workable competition," a market situation which is only vaguely defined and which constitutes the optimum available, judged by criteria such as industry efficiency, profit pattern, freedom of entry and adaptability to defense needs. See, e.g., Adelman, Effective Competition and the Antitrust Laws, 61 Harv. L. Rev. 1289 (1948); Stocking, The Rule of Reason, Workable Competition, and Monopoly, 64 Y ALE L.J. 1107, 1108-12, 1161-62 (1955).

The antitrust laws have dee $p$ social significance; they are viewed as one means by which democratic ideals are preserved, allowing economic as well as political freedom. A dominant purpose presently attributed to the antitrust laws is that of preserving the small competitor to allow the individual the greatest possible freedom as entrepreneur, employee and purchaser; and to prevent America from becoming a nation of employees. See United States v. Aluminum Co., 148 F.2d 416, 427 (2d Cir. 1945) ; United States v. Columbia Steel Co., 334 U.S. 495, 535-36 (1948) (dissenting opinion) ; S. Rep. No. 1775, 81st Cong., 2d Sess. . 3 (1950); Loevinger, Antitrust, Economics and Politics, 1 Asturrust Buld. 225 (1955); Comment, 66 YALE L.J. 69 (1956). In addition, antitrust laws preclude concentration of great power in the hands of a few-a result which is feared, specifically because of the economic and political potentialities inherent in use of such power. See, e.g., Jones, The Problcm. of Size in Antitrust Thinking: Thearies in Search of Facts, 3 U.C.L.A.L. REv. $141\left(19 \mathfrak{s}^{5}\right)$.

2. Some practices are proscribed by express statutory provisions:

Discrimination in price: Robinson-Patman Act $\S 1$, 49 STAT. 1526 (1936), 15 U.S.C. $\S 13$ (1952), amending Clayton Act, c. 323, § 2, 38 Stat. 730 (1914). See, generally, Report if the Attorney General's National Committee to Study the Antitrust Laws 155-221 (1955) (hereinafter cited as ATT'y GEN. REP.).

Tying and requirement contracts: Clayton Act $\$ 3,38$ STAT. 731 (1914), 15 U.S.C. $\$ 14$ (1952). See Standard Oil Co. v. United States, 337 U.S. 293 (1949); International Salt 
tion has been the subject of controversy based on conflicting notions of the value and effect of centralized business structure. ${ }^{3}$ Today, many industries are dominated by small groups of large and powerful firms, ${ }^{4}$ which, by their very existence, significantly affect price and production levels. ${ }^{5}$ Yet the market

Co. v. United States, 332 U.S. 392 (1947) ; cf. Times-Picayune Publishing Co. v. United States, 345 U.S. 594 (1953).

Mergers: Celler-Kefauver Act, 64 STAт. 1125 (1950), 15 U.S.C. $\$ 18$ (1952), amending Clayton Act, c. 323, $\$ 7,38$ Stat. 731 (1914). See Strichartz, The Anti-Merger Act: A Legal-Economic Analysis, 2 Howard L.J. 57 (1956).

Other objectionable practices are condemned by the provisions of the Sherman Act generally :

Price Fixing: Compare United States v. Trenton Potteries Co., 273 U.S. 392 (1927); United States v. Socony-Vacuum Oil Co., 310 U.S. 150 (1940) (price fixing a per se violation), with Board of Trade v. United States, 246 U.S. 231 (1918) ; Appalachian Coals, Inc. v. United States, 288 U.S. 344 (1933) (no price fixing).

Resale price maintenance: Kiefer-Stewart Co. v. Joseph E. Seagram \& Sons, Inc., 340 U.S. 211 (1951) ; Dr. Miles Medical Co. v. John D. Park \& Sons Co., 220 U.S. 373 (1911). But Congress has expressly permitted resale price maintenance on trade-marked goods in those states allowing fair trade. Miller-Tydings Act, 50 StAT. 693 (1937), 15 U.S.C. $\$ 1$ (1952); McGuire Amendment to the Federal Trade Commission Act, 66 Stat. 631, 15 U.S.C. $\$ 45$ (1952).

Group boycott: Associated Press v. United States, 326 U.S. 1 (1945) ; Fashion Originators' Guild, Inc. v. FTC, 312 U.S. 457 (1941).

Market division: Timken Roller Bearing Co. v. United States, 341 U.S. 593 (1951). There have been no cases in which the only offense charged was market division. ATT'Y GEN. REP. 26. The Timken case has been extensively noted due to its announcement of the doctrine of intra-enterprise conspiracy. See, e.g., Comment, Intra-Enterprise Conspiracy Under the Sherman Act, 63 Y ALE L.J. 372 (1953). See also note 52 infra.

3. See, e.g., Temporary National Economic Committee, Final Report and Recommendations, S. Doc. No. 35, 77th Cong., 1st Sess. 11-19, 23 (1941) (hereinafter cited as TNEC, Final REPoRT) ; S. Rep. No. 1775, 81st Cong., 2d Sess. 3 (1950) ; H.R. Rep. No. 1191, 81st Ceng., 1st Sess. 2-5 (1949); Handler, Industrial Mergers and the Anti-Trust Lazes, 32 Colum. L. Rev. 179, 271 (1932) ; note 15 infra.

4. See FTC, Report on Changes in Concentration in Manufacturing, app. D (1954) (concentration in value of product and employment for first four, and first eight companies in 356 industries as of 1935, 1947 and 1950) ; FTC, REPORT ON THE CONCENTRATION OF PRoDuctrve Facrlitres 21 (1947) (percentage of net capital assets held by leading companies in twenty-six selected manufacturing industries); WeSTON, THE RoLE of MERgers IN THE Growth of LARGe FirMs $39-41$ (1953) (percentage of total output for representative years between 1891 and 1.948 by the leading firms in the motor vehicle, cigarette, aluminum, cement, electrical machinery, meat packing, rubber tire and tin can industries).

5. Oligopoly behavior has but recently been critically studied. Externally, oligopolistic firms act to prevent entry into their industry. By threats of cut-throat competition and harrowing litigation combined with foreclosure of sources of supply and technical ability, the oligopolist often frightens away a potential competitor. Such behavior limits the number of available competitors, and makes the consumer increasingly dependent on existing productive units. Internally, with a limited number of firms existing, outright co-operation is facilitated. But, in a market dominated by a small number of large firms, co-operation may be unnecessary to minimize competition; absence of competition can inhere in the context. Each firm is aware that any competitive price action it takes may immediately be duplicated by the other firms, wiping out any individual advantage. Thus each firm con- 
power of these units alone is often insufficient to expose them to antitrust censure. $^{6}$ For established judicial construction may deny application of the Sherman Act, the major weapon for inhibiting undue industrial centralization. ${ }^{7}$

cludes that its most beneficial policy is never to lower prices and, in some forms of oligopoly, to raise prices as far as competition from substitute products and consumer demand will allow. The small firms, even if they so desired, have no choice but to follow; any competitive behavior upon their part may be met by reprisals similar to those facing an attempted intruder. In sum, the concentrated industry by its very nature can result in identical anti-competitive patterns as are found to exist in monopoly, and which do result when various firms expressly agree not to compete. But oligopoly market structure is socially more desirable than monopoly structure. An oligopoly will not necessarily result in competitive patterns similar to monopoly. And an oligopolist is likely to compete by means other than price-principally through innovation. See FeLLNER, CoMrpetition Among tee Few (1949) ; Machlup, The Political Economy of Monopoly c. 4 (1952); Conant, Conscions Parallel Action in Restraint of Trade, 38 MINN. L. Rev. 797 (1954); Comment, 64 Y YLE L.J. 1049 (1955); Note, 66 Y ALE L.J. 243, 252-56 (1956). But see National Lead Co. v. FTC, 227 F.2d 825, 834 (7th Cir. 1955), cert. granted, 351 U.S. 961 (1956), cert. denied to petitioner below, 351 U.S. 964 (1956) (existence of other forms of competition does not justify lack of price competition).

The increased understanding of oligopoly behavior has been reflected in the judicial treatment of industries characterized by a limited number of dominant firms. Compare United States v. United States Steel Corp., 251. U.S. 417, 451 (1920) (competition cannot be compelled and size not an offense although it results in price imitation), with American Tobacco Co. v. United States, 328 U.S. 781 (1946) (parallel action rather than actual agreement emphasized) ; Interstate Circuit, Inc. v. United States, 306 U.S. 208 (1939). See explanatory decision in Theatre Enterprises, Inc. v. Paramount Film Distribution Corp., 346 U.S. 537, 541 (1954) (conspiracy remains a necessary element of $\$ 1$; in oligopoly situation, parallel action is but one form of evidence of agreement). On the doctrine of "conscious parallelism" generally, see Atr'y GeN. Rep. 36-42; Note, 52 Mich. L. Rev. 1076 (1954).

6. Industrial giants controlling tremendous percentages of a market exist free of prosecution. See note 4 supra. When prosecuted, they often escape antitrust conviction or are not forced into dissolution. See United States v. International Harvester Co., 274 U.S. 693 (1927) (producer of about $85 \%$ of harvesting equipment); United States v. United States Steel Corp., 251 U.S. 417 (1920) (producer of approximately 50\% of steel) ; United States v. United Shoe Machinery Co., 247 U.S. 32 (1918) (producer of almost entire market in shoe machinery). They are even allowed to acquire new productive facilities through merger. See United States v. Columbia Steel Co., 334 U.S. 495 (1948) (U.S. Steel permitted to acquire largest independent west coast steel fabricator). Of course, when the firm is in restraint of trade through combination with other firms, United States v. SoconyVacuum Oil Co., 310 U.S. 150 (1940), or controls such a great percentage of the market that it is in violation of the monopoly provisions of $\S 2$ of the Sherman Act, United States v. Aluminum Co., 148 F.2d 416 (2d Cir. 1945), illegality follows. See notes 11-13 infra.

7. $26 \mathrm{~S}_{\mathrm{TAT}} 209$ (1890), 15 U.S.C. $\S \S 1-7$ (1952). "The purpose [of the Clayton Act] is only to supplement [the Sherman Act] .... Broadly stated, the bill, in its treatment of unlawful restraints and monopolies, seeks to prohibit and make unlawful certain trade practices which, as a rule, singly and in themselves, are not covered by the Act of July 2, 1890 ...." S. REP. No. 698, 63d Cong., 2d Sess. 1 (1914).

All antitrust legislation subsequent to the Sherman Act has been directed to certain practices not adequately covered by the Sherman Act, or to new means by which the provisions of the Sherman Act are to be enforced. The principal legislation has been the Federal Trade Commission Act, 38 Stat. 717 (1914), as amended, 15 U.S.C. $\$ 41-54$ (1952), 
The act provides two methods of controlling economic concentration. Section 2 deals with concentration itself, and declares power reaching monopoly proportions illegal. Section 1 , in contrast, is directed to the means by which economic power may be achieved. It proscribes restraints of trade engendered by contract, combination or conspiracy. ${ }^{9}$ Thus two or more parties are required to effect a section 1 violation..$^{10}$ Although the courts have adopted a fairly broad standard for judging restraints under section 1,11 they have, commencing with

which established the Federal Trade Commission and authorized it to prevent "unfair methods of competition in commerce," 38 STAT. 719 (1914), 15 U.S.C. $\$ 45$ (a) (1) (1952), and the Clayton Act, 38 STAT. 730 (1914), as amended, 15 U.S.C. $\$ \$ 12-27$ (1952), which deals, inter alia, with price discrimination, tying contracts and mergers. For a complete listing of antitrust legislation, see Antitrust Laws witr Anendments 1890-1956 (U.S. Govt. Printing Office 1956).

8. "Every person who shall monopolize, or attempt to monopolize, or combine or conspire ... to monopolize any part of the trade or commerce among the several States, or with foreign nations, shall be deemed guilty of a misdemeanor . ..." 26 STAT. 209 (1890), 15 U.S.C. $\$ 2$ (1952). The thrust of $\$ 2$ is directed to power itself. American Tabacco Co. v. United States, 328 U.S. 781, 810-15 (1946) (citing with approval United States v. Aluminum Co., 148 F.2d 416 (2d Cir. 1945)) ; Robbins, "Bigness," The Sherman Act, and Antitrust Policy, 39 VA. L. Rev. 907 (1953); see Rostow, The New Sherman Act: A Positive Instrument of Progress, 14 U. CHx. L. REv. 567 (1947).

9. "Every contract, combination in the form of trust or otherwise, or conspiracy, in restraint of trade or commerce among the several States, or with foreign nations, is hereby declared to be illegal. Every person who shall make any such contract or engage in any such combination or conspiracy, shall be deemed guilty of a misdemeanor . . ." 26 STAT. 209 (1890), 15 U.S.C. $\$ 1$ (1952).

The exact meaning of "combination" and "conspiracy" is unclear. In case law, the terms are generally used interchangeably. See, e.g., American Column \& Lumber Co. v. United States, 257 U.S. 377 (1921). Commentators have found no sensible distinction in their meanings. See Rahl, Conspiracy and the Anti-Trust Lawes, 44 ILI. L. REv. 743, 744 n.5 (1950); Note, 100 U. PA. L. Rev. 1006, 1007-08 (1952).

10. The existence of a restraint of trade is not in itself sufficient to effect a $\$ 1$ violation. The restraint must be effected by a combination, contract or conspiracy; thus, by two or more persons acting together. Eastern States Retail Lumber Dealer's Ass'n v. United States, 234 U.S. 600, 614 (1914). See Times-Picayune Publishing Co. v. United States, 345 U.S. 594, 624-28 (1953) ; United States v. Socony-Vacuum Oil Co., 310 U.S. 150, 224 n.59 (1940) (conspiracy a $\$ 1$ violation even though the parties are incapable of unreasonable restraints of trade). Cf. Allen Bradley Co. v. Local 3, Int'1 Brotherhood of Elec. Workers, 325 U.S. 797 (1945) (although labor combination exempted from antitrust laws, when labor combines with business groups to restrain trade the combination is not insulated from \& 1 violations).

Recently, courts have invoked the doctrine of intra-enterprise conspiracy whereby individual corporate members of the same firm are capable of conspiring in violation of $\S 1$. See, e.g., United States v. Yellow Cab Co., 332 U.S. 218 (1947). Since a single firm in reality acts as a unit, this doctrine might seem a relaxation of the multiple party requirement of $\S 1$. But see note 52 infra.

11. Originally, the courts interpreted literally $\S 1$ 's proscription of "every contract ... in restraint of trade." See United States v. Trans-Missouri Freight Ass'n, 166 U.S. 290 (1897); United States v. Joint Traffic Ass'n, 171 U.S. 505 (1898). But since Standard Oil Co. v. United States, 221 U.S. 1 (1911), only those contracts, combinations or conspiracies unreasonably restraining trade violate the act. See note 13 infra. 
the decision in United States $v$. United States Steel Corp. ${ }^{12}$ required a high degree of market power before finding a violation of section $2 .{ }^{13}$ Accordingly a non-monopolistic firm will avoid Shernan Act strictures even though of itself it may produce results identical with those punished under sections 1 and $2 .^{14}$

12. 251 U.S. 417 (1920). United States Steel, a holding company which at formation controlled $\$ 0-90 \%$ of the steel output of the country, was prosecuted under $\$ \$ 1$ and 2 . At the time of suit, control had dropped to 50\%. Although the Court found that at formation the intent was to restrain and monopolize trade, at the time of suit, United States Steel could not impose its will on the other firms in the industry, "could not fix prices and thus was not violating $\$ 1$. The Court implicitly held that $50 \%$ of the market was insufficient control for a violation of $\$ 2$.

13. See United States v. Aluminum Co., 148 F.2d 416, 424 (2d Cir. 1945) (90\% share of a market constitutes monopoly control, but a 33\% share does not and 60-64\% probably does not). See also, United States v. International Harvester Co., 274 U.S. 693, 709 (1927) ; Adelman, Effective Competition and the Antitrust Lazes, 61 Harv. L. Rev. 1289, 1307-11 (1948) ; Rostow, Over-All Size, in How to Consply with the Antitrust Laws 311, 315 (Van Cise \& Dunn ed. 1954).

Traditionally, the loose-knit combination-union of competitors by agreement but without any property link-has been distinguished from the single trader or close-knit combination-firm formed through union by permanent property interchange. See American Column \& Lumber Co. v. United States, 257 U.S. 377, 418 (1921) (dissenting opinion); Weston, The Application of the Sherman Act to "Integrated" and "Loose" Industrial Combinations, 7 Law \& Contemp. Prob. 42 (1940); Handler, Industrial Mergers and the Anti-Trust Laws, 32 CoLux. L. REv. 179 (1932). But see Appalachian Coals, Ine. v. United States, 288 U.S. 344, 376-77 (1933). Since the required multiplicity of parties always exists in a loose-knit combination, it is open to a charge of $\$ 1$ violation throughout its existence. See, e.g., Eastern States Retail Lumber Dealers' Ass'n v. United States, 234 U.S. 600 (1914). A close-knit combination is free of any $\$ 1$. violation for its individual conduct so long as the formation is not itself illegal. For once a legal formation by combination is effected, the multiple parties no longer exist. Illegality at formation would result either when the merger is of such proportions that it effects an unreasonable restraint, or where the acquisitions are made as part of an over-all scheme to effect a restraint, although each union is not in itself of unreasonable proportions. See United States v. Southern Pac. Co., 259 U.S. 214 (1922) (railroad merger itself a restraint); United States v. Union Pac. R.R., 226 U.S. 61 (1912) (same) ; Standard Oil Co. v. United States, 221 U.S. 1 (1911) (scheme of acquisition); United States v. American Tobacco Co., 221 U.S. 106 (1911) (same). The only ground for prosecuting the single trader, close-knit combination is monopolization under $\S 2$. And the degree of market control required for a firm to be in violation is higher than that required for an unreasonable restraint under \$1. See AtT'y Gen. Rep. 43.

The basis of this distinction is unclear. It most likely stems from the belief that the close-knit combination offers those advantages of scale which are socially useful-efficiency, stabilizing influence on the economy, resources to advance technology-and that these in part balance the disadvantages of concentration. Since the advantages of scale do not inhere in the loose-knit combination, this form of union can not as easily be justified. See MACHlup, The Politigal Economy of Monopoly c. 3 (1952); Letwin, Congress and the Sherman Antitrust Law: 1887-1890, 23 U. CHI. I. REv. 221, 237-39 (1956); Van Cise, The Modern Corporation and the Antitrust Laws: From Trust to Distrust, 19 U. CHI. L. Rev. 668 (1952). For a detailed discussion of the characteristics and judicial treatment of looseknit combinations, see Hale, Agreements Among Competitors: Incidental and Reasonable Restraints of Trade, 33 MINN. L. Rev. 331 (1949).

14. See note 5 supra. 
Nevertheless, proponents of greater control over centralization have not succeeded in effecting legislation designed to meet this problem. ${ }^{15}$ Rather, legislation subsequent to the Sherman Act has merely sought to regulate certain anti-competitive practices not adequately controlled by that act, ${ }^{16}$ or as in section 7 of the Clayton Act, to prevent future crystallization into anti-competitive units by restricting corporate stock acquisitions and mergers. ${ }^{17}$

15. See note 7 supra. "[The Clayton Bill] is a distinct disappointment to those who sincerely desire to destroy private monopoly. The question of suppression of trusts receives only incidental consideration. Instead of directly dealing with the trust problem, which was the original program, the committee has turned to side issues, such as discrimination in price, exclusive contracts .... In so far as this bill touches the problem of private monopoly at all, it legislates in an arbitrary way against the form of the evil and not against the substance." H.R. REP. No. 627, 63d Cong., 2d Sess., pt. 3, at 1. (1914) (minority view).

Commentators presently disagree on the desirability of breaking up the large anti-competitive firms. Aside from the basic conflict on the value of great concentration in industry, some argue that there is no proof that twenty firms in an industry will compete more effectively than three or four. E.g., Weston, op. cit. supra note 4, at 89-90; Bowman, Towvard Less Monopoly, 101 U. PA. L. Rev. 577, 631-41 (1953). But this line of argument ignores the fact that actual agreement is effected more easily among a small group of competitors. It also ignores the truths of oligopoly behavior. See note 5 supra. The argument that extensive splitting of large corporations might impair the effectiveness of American industrial structure and place an inordinate burden on the judicial process appears more valid. Further support for this position lies in the argument that the actual effect of industrial concentration cannot be satisfactorily measured. For presentations of the arguments pro and con, see, e.g., Jones, The Problems of Size in Antitrust Thinking: Theories in Search of Facts, 3 U.C.L.A.L. Rev. 141 (1956) ; Loevinger, Antitrust, Economics and Politics, 1 Antitrust Buld. 225 (1955). See, generally, National Bureau Committre for Economic Research, Business Concentration and Price Policy (1955).

16. See notes 2,7 supra.

17. Prior to amendment in $1950, \S 7$ provided: "That no corporation engaged in commerce shall acquire, directly or indirectly, the whole or any part of the stock or other share capital of another corporation engaged also in commerce, where the effect of such acquisition may be to substantially lessen competition between the corporation whose stock is so acquired and the corporation making the acquisition, or to restrain such commerce in any section or community, or tend to create a monopoly of any line of commerce." 38 STat. 731. (1914). Other provisions of the section established exceptions to this broad ruling, including an exception as to acquisitions purely for investment.

In 1950, the section was amended to read that: "No corporation engaged in commerce shall acquire, directly or indirectly, the whole or any part of the stock or other share capital and no corporation subject to the jurisdiction of the Federal Trade Commission shall acquire the whole or any part of the assets of another corporation engaged also in commerce, where in any line of commerce in any section of the country, the effect of such acquisition may be substantially to lessen competition, or to tend to create a monopoly." 64 STAт. 1125 (1950), 15 U.S.C. \& 18 (1952). Similar exceptions were preserved. The amendment was intended to remove certain loopholes and limitations existing in the earlier formulation of the section: in particular, the applicability to stock acquisitions alone; and the test based on competition between the acquired and the acquiring corporations. See notes 26-32, 37-40 infra.

Extensive comment followed the 1950 revision. See, e.g., Carson, Corporate Mferger, in How to Comply with the Antitrust Laws 279 (Van Cise and Dunn ed. 1954); Comment, The Amendment to Section 7 of the Clayton Act, 46 ILL. L. Rev. 444 (1951). See also, Comment, 57 YaLE L.J. 613 (1948). 
Presumably motivated by the absence of more stringent legislative regulation, the Supreme Court modified the antitrust laws in the recent case of United States v. E. I. Du Pont De Nemours and Co. ${ }^{18}$ The complaint, filed in 1949, alleged that Du Pont had used and was using its twenty-three per cent stock interest in General Motors Corporation to acquire the General Motors' business in fabrics, finishes and other automotive products. ${ }^{19}$ Claiming a resulting conspiracy to monopolize and restrain trade, the government charged Du Pont with violations of sections 1 and 2 of the Sherman Act, and section 7 of the Clayton Act. ${ }^{20}$ The district court, stating that the facts disclosed no conspiracy, no actual or probable unreasonable restraint or tendency to monopolize trade, and thus no antitrust violation, dismissed the case. ${ }^{21}$ On direct appeal to the Supreme Court, the trial court was reversed in a four to two decision. ${ }^{22}$ Without passing on the question of Sherman Act violation, ${ }^{23}$ the Court held that the 1917-1919 Du Pont purchase of General Motors stock constituted a violation of section 7 of the Clayton Act as formulated prior to amendment in $1950 .^{24}$ It found section 7 applicable to vertical as well as horizontal stock acquisitions, and defined the relevant market in which to consider the competitive effect of the Du Pont-General Motors' relationship as that for automobile fabrics and finishes. Moreover, the Court ruled that, for purposes of section 7, the market effect of a stock acquisition should be considered as of the time suit is brought rather than when the merger occurred and that, in the instant case, the market effect was within the proscription of section 7.25

Section 7 of the Clayton Act was enacted in 1914 to forestall industrial con-

18. 77 Sup. Ct. 872 (1957). The Court's concern over the lack of broad control of concentration is demonstrated by the effect of its decision. See pages 1259-61 infra. Cf. note 52 infra.

19. Transcript of Record, pp. 226-28, United States v. E. I. Du Pont De Nemours and Co., 126 F. Supp. 235 (N.D. Ill. 1954). Also alleged as a violation was Du Pont's acquisition of stock in United States Rubber Company, and use of stock control of General Motors Corporation to gain a protected market for tires and tubes.

20. Id. at $219-20$.

21. United States v. E. I. Du Pont De Nemours and Co., 126 F. Supp. 235, 334-35 (N.D. Ill. 1954). The court traced in detail the process of Du Pont acquisition of General Motors and United States Rubber stock. Id. at 238-65. It then examined the purchasing policy for each of the products which $\mathrm{Du}$ Pont supplied to General Motors, including finishes, fabrics, tetraethyl lead, synthetic rubber and antifreeze. It found that each of General Motors' divisions pursued an independent purchasing policy, that the degree of use of Du Pont products varied markedly with the division and the product and that in all cases Du Pont had achieved its business on a competitive basis. Id. at 288-335.

22. 77 Sup. Ct. at 872 . See 32 Stat. 823 (1903), as amended, 15 U.S.C. $\$ 29$ (1952) (authorizing direct appeal in antitrust cases).

23. 77 Sup. Ct. at 875 n.5.

24. Id. at 874 n.4. See note 17 supra. The provisions of amended $\$ 7$ apply only to acquisitions which are effected subsequent to passage of the amendment in 1950 . For acquisitions occurring prior to the amendment. $\$ 7$ as originally formulated applies. 64 Stat. 1126 (1950), 15 U.S.C. \& 18 (1952).

25. 77 Sup. Ct. at 884 . 
centration. ${ }^{26}$ Directed at corporate growth through merger, it made acquisition of stock in one corporation by another illegal where "the effect of such acquisition may be to substantially lessen competition between [the corporations] ... to restrain commerce or tend to create a monopoly. . ."." In $D u$ Pont, the Court for the first time extended this provision to a vertical stock acquisition. ${ }^{28}$ While this holding conflicts with the long-standing Federal Trade Commission ruling confining application of the section to horizontal acquisitions, it need not be considered an unwarranted interpretation of the statute. ${ }^{29}$ Both the original congressional intent and the authority for the Commission's ruling are unclear. ${ }^{30}$ And not only is the wording of the statute broad enough to cover

26. See S. Rep. No. 698, 63d Cong., 1st Sess. 1, 13 (1914). As reported, § 7, then $\S 8$, was directed at "holding company" growth; the practice of stock acquisition was thought objectionable as a common method of creating monopoly. And the Clayton Act was intended to reach restraints in their incipiency. See S. REP. No. 1775, 81st Cong., 2d Sess. 4-5 (1950) ; Transamerica Corp. v. Board of Governors, 206 F.2d 163 (3d Cir. 1953) ; V. Vivaudou, Inc. v. FTC, 54 F.2d 273 (2d Cir. 1931). Of course, $\$ 7$ reaches only one of the methods by which corporations may grow ; that is, external expansion-acquisition of another. And internal expansion-use of corporate assets to build new productive facilities-has accounted for a dominant proportion of industrial growth. FTC, SUMmaRY REPORT oN the Merger Mavenent 22-28 (1948). See note 42 infra.

27. 38 Stat. 731 (1914), as amended, 15 U.S.C. $\$ 18$ (1952). See notes 17, 24 supri.

28. Horizontal acquisition involves firms which produce roughly the same product. Vertical acquisition involves firms, one of which uses the product of the other as a step in its production cycle. Conglomorate acquisition applies to firms which have no discernible relationship in the nature of their business. Machlup, The Political Econosiy of Monopoly c. 4 (1952) ; FTC, Sundrary Report on the Merger Movement $29-66$ (1948). For a discussion of these three categories of acquisitions and a statistical analysis of their relative role in merger activity, see $i d$. at 29-63. For an economic-legal analysis of the integrated firm, see Adelman, Corporate Integration, in How to Corrply WITH the ANTITRUST Laws 290 (Van Cise and Dunn ed. 1954).

29. FTC Ann. Rep. 6-7, 60 (1929); FTC, Report on Corporate Miergers and AcQuisitions 154-55, 168 (1955).

Many commentators have agreed with the FTC ruling, and have stated that $\$ 7$ prior to amendment was applicable to horizontal stock acquisitions alone. See, e.g., Comment, 27 Tur. L. Rev. 332 (1953). But see Ronald Fabrics Co. v. Verney Brunswick Mills, Inc., CCH TRADE REG. REP. (1946-47 Trade Cas.) I 57514 (S.D.N.Y. 1946). This case involved a private antitrust suit for treble damages. Defendant, a rayon converter and a competitor of plaintiff, was charged with illegally purchasing the stock of plaintiff's principal supplier of rayon greige goods. The court denied a motion to dismiss, stating that "[\$ 7] . . is in the disjunctive and does not alone apply to substantial lessening of competition between the corporation whose stock was acquired and the corporation acquiring it, but also comprehends a situation where the effect of the acquisition is to restrain commerce or tend to create a monopoly." See also H.R. Rep. No. 1191, 81st Cong., 1st Sess. 11 (1949) (amendment was in part due to the fact that "it has been thought by some that this legislation [old § 7] applies only to the so-called horizontal mergers" and "to make clear that $\S 7$ applies to all types of mergers and acquisitions"). (Emphasis added.) See note 32 infra.

30. See Hearings on Trust Legislation Before the House Committee on the Judiciary, 63d Cong., 2d Sess., ser. 7, pt. 1-35 (1914) ; S. Rep. No. 698, 63d Cong., 2d Sess. (1914); H.R. REP. No. 627, 63d Cong., 1st Sess. (1914) ; Debates (reported in various parts of 51 Cong. ReC. (1914)); FTC ANN. Rep. 7, 60 (1929). 
such acquisitions, ${ }^{31}$ but the inclusion conforms to the congressional policy illustrated in the 1950 amendment of section $7 .^{32}$ In contrast, the treatment of market definition cannot readily be justified. The Court reversed the detailed and carefully analyzed findings of the district court with little explanation beyond the statement that automobile fabrics and finishes constituted a market in themselves, and that Du Pont had used its 1917-1919 stock acquisition to obtain a share of that market sufficiently substantial to violate the section. ${ }^{33}$

More important is the unprecedented ruling that the market effect existing at the time of suit should determine the legality of the stock acquisition. ${ }^{34}$ In

31. Section 7 is written in the disjunctive. In addition to proscribing acquisitions which lessen competition between the acquiring and acquired corporations and which are necessarily horizontal since the corporations are competitors, it finds illegality where an acquisition may restrain commerce in a section or community, or tend to create a monopoly. Naturally, a vertical acquisition could fulfill such requirements. See, e.g., United States v. Columbia Steel Co., 334 U.S. 495 (1948) ; Ronald Fabrics Co. v. Verney Brunswick Mills, Inc., CCH Trade Reg. Rep. (1946-47 Trade Cas.) If 57514 (S.D.N.Y. 1946). See also Aluminum Co. v. FTC, 284 Fed. 401 (3d Cir. 1922) (both sides of disjunctive in $\$ 7$ not synonymous); United States v. New England Fish Exchange, 258 Fed. 732 (D. Mass. 1919) (same).

32. 64 Stat. 1125 (1950), 15 U.S.C. $\$ 18$ (1952). See H.R. Rep. No. 1191, 81st Cong., 1st Sess. 11 (1949); note 29 supra. Congressional policy in turn conforms to the existing attitude that vertical integration is a means of establishing monopoly, and of acquiring a stranglehold on a market either through control of a critical area of production or distribution or through the amassing of economic power. Dirlan \& KAHN, FaIR CoMI ctiTuin 22-23, 141-50 (1954). But see Bork, Vertical Integration and the Sherman Act: The Legal History of an Economic Misconception, 22 U. CHI. L. Rev. 157 (1954) ; Comment, 19 U. CHI. L. REv. 583 (1952).

33. 77 Sup. Ct. at $877-80$.

34. The Clayton Act was intended to arrest the creation of trusts and monopolies in their incipiency. See note 26 supra. In $D u$ Pont, the Court interprets incipiency under $\$ 7$ to mean the "... time when the acquisition threatens to ripen into a prohibited effect." 77 Sup. Ct. at 879.

Section 7 had always been judicially interpreted to require that the objectionable effect be judged as of the time of merger. International Shoe Co. v. FTC, 280 U.S. 291 (1930) (prosecution under "lessening of competition between acquiring and acquired" phrase of \$7; acquisition can not produce forbidden result if there is no substantial pre-existing competition at time of merger); Transamerica Corp. v. Board of Governors, 206 F.2d 163 (3d Cir. 1953) (Clayton Act to arrest at incipiency acts and practices which ripen to Sherman Act violation); V. Vivaudou, Inc. v. FTC, 54 F.2d 273 (2d Cir. 1931) (Clayton Act to prevent at incipiency forms of combination which Sherman Act might not reach until evil existed); FTC v. Thatcher Mfg. Co., 5 F.2d 615 (3d Cir. 1925), rev'd in part on other grounds, 272 U.S. 554 (1926) (effect of transaction determines $\$ 7$ legality); United States v. Republic Steel Corp., 11 F. Supp. 117 (N.D. Ohio 1935) (same). Cf. Standard Fashion Co. v. Margrane-Fouston Co., 258 U.S. 346 (1922) (Clayton Act sought to reach the agreements embraced within its sphere in their incipiency). And see dissenting opinion in Du Pont showing how $\$ 7$ would have to be phrased to justify the Court's interpretation. 77 Sup. Ct. at 891.

Congress clearly contemplated that the time of acquisition was to be the period for judging $\$ 7$ legality. See, e.g., Hearings Before Subcommittee No. 3 of the House Committee on the Judiciary, 79th Cong., 1st Sess. 56 (1945) ; H.R. REP. No. 627, 63d Cong., $2 \mathrm{~d}$ Sess., pt. 2, at 6 (1914) (minority view). See also the TNEC's statement that the purpose of $\S 7$ is to halt the merger process at its inception and suggestion that rather 
the context of the antitrust laws generally, the wisdom of this judicial redefinition enlarging the scope of section 7 to regulate business concentration is questionable. Alternatively, the provisions of the Sherman Act might have been reinterpreted to control centralized industry more effectively: the standards of monopoly under section 2 might have been reduced, or the existing interpretation of the contract, combination and conspiracy requirements of section 1 might have been broadened. ${ }^{35}$ In expanding section 7 instead through making the time of suit rather than the time of merger the point for judging market effect of a challenged acquisition, the Court sanctioned antitrust attack upon any corporation which, having once effected a stock acquisition-no matter how innocuous-subsequently grew to a position of market dominance. But section 7 was formulated to prevent acquisitions which in themselves were potentially harmful. ${ }^{36}$ Accordingly, the standard of legality was lower than that of the Sherman Act, requiring only a showing of reasonable probability, not an actual restraint of trade. ${ }^{37}$ Within the original framework of the act, this test was sensible. A liberal standard was necessary to reach restraints not yet assuming Sherman Act proportions. Also, as the immediate market effect of the merger determined legality, property rights which suffered from a finding of violation were both created and destroyed by the challenged acquisition itself. Subsequent developments could affect such rights only upon proof of a new acquisition offending section 7, or a showing of actual restraint or monopolistic practice activating the proscriptions of sections 1 and 2 of the Sherman Act. By giving section 7 a new frame of reference, the Court, founding illegal-

than a system of case by case litigation after the merger, the standards of $\S 7$ should be based upon examination and approval or disapproval prior to the merger itself. TNEC, FINAL REPORT 38-40 (1941). Clearly, no such system would be operable if the conditions existing at the time of suit, rather than the time of merger, were to govern legality.

35. See note 53 infra and accompanying text.

36. Section 7 is prospective in view, looking toward the future effect of an acquisition. See Barnes, Economic Issues in the Regulation of Acquisitions and Mergers, 14 OH10 ST. L.J. 279, 288 (1953). This effect, before $D u$ Pont, was to be judged by the market positions of the firms at the time of the acquisition. See note 34 supra (collecting cases).

37. Section 7's proscription of mergers whose effect "may be" to lessen competition substantially has been interpreted to require only a reasonable probability that competition will be reduced for a finding of illegality. See, e.g., International Shoe Co. v. FTC, 280 U.S. 291,298 (1930). But $\S 7$ does require a showing greater than a mere possibility of restraint. And the quantitative substantiality test, established for $\S 3$ in Standard Oil Co. v. United States, 337 U.S. 293,314 (1949), has been rejected as inapplicable to $\$ 7$. Transamerica Corp. v. Board of Governors, 206 F.2d 163, 170 (3d Cir. 1953). For discussion of subsequent judicial and administrative treatment of Transancrica, see ATT'y GEN. REP. 119-25. See also S. Rep. No. 1775, 81st Cong., 2d Sess. 6 (1950) ; Barnes, Markets, Competition, and Monopolistic Tendencies in Merger Cases, 40 MARQ. L. Rev. 141 (1956); Donovan, Mergers and the Antitrust Lazus, 1 Antrtrust Buld. 179 (1955).

The criteria used by the Justice Department to measure the effect and the legality of a merger are listed and explained in Strichartz, The Anti-Merger Act: A Legal-Economic Analysis, 2 Howard L. Rev. 57, 66-74 (1956). They include, inter alia, industry structure and ease of entry, the relative positions of the two corporations in the industry and their past activities. 
ity on subsequent developments, has subjected a corporation to the severe penalties flowing from antitrust violation without requiring a new, objectionable acquisition or a showing of actual restraint or monopolistic behavior. ${ }^{38}$

Furthermore, an expanded section 7 is not an effective means of controlling industrial concentration. Prior to amendment in 1950, section 7 was applicable to stock acquisitions only $;^{39}$ a union of assets could not be attacked even though effected subsequent and pursuant to a stock union. ${ }^{40}$ Thus firms whose only acquisitions occurred prior to 1950 and involved assets rather than stock cannot be challenged under even the extended scope of the $D u$ Pont redefinition of section 7.41 More important, under any antitrust legislation, a general competitive test dependent for its effectiveness upon a merger of corporate interests is not a useful weapon for industrial control. The recent preoccupation with mergers has obscured the fact that long-term industrial growth has resulted primarily from internal expansion. ${ }^{42}$ Although in many respects great industrial accumulations may be objectionable, abstract size is no measure of antitrust illegality; technological efficiency often requires industrial concentration of vast proportions. ${ }^{43}$ But present antitrust theory is centered on the firm

38. The effect of the holding in $D_{u}$ Pont is to reverse the long standing distinction existing between the loose-knit and close-knit combination. See note 13 supra. While a showing of actual unreasonable restraint is still required for the loose-knit combination to be in violation of $\$ 1$, see note 11 supra, the close-knit combination can now be judged according to the more relaxed standards of $\$ 7$, requiring a showing of only a reasonable probability of restraint. See note 37 supra.

39. S. Rep. No. 1775, 81st Cong., 2d Sess. 2 (1950).

40. See Arrow-Hart \& Hegeman Elec. Co. v. FTC, 291 U.S. 587, 598-99 (1934) (Commission's power under $\$ 7$ limited strictly to ordering a dive'stiture of stock originally acquired, no power to order divestiture of assets acquired after complaint filed for illegal stock acquisition); Thatcher Mfg. Co. v. FTC, 272 U.S. 554, 561 (1926) (FTC may not obtain divestment of assets acquired before it commences proceedings). But cf. FTC v. Western Meat Co., 272 U.S. 554, 559 (1926) (Commission may obtain injunction to prevent use of stock to acquire assets). The practice of acquiring the assets of a corporation immediately following the purchase of the corporation's stock has been extensively followed in order to avoid the provisions of $\$ 7$. See FTC, Sumiany Report on the MERGER Movement 3-6 (1948).

41. And many corporations in this period followed the practice of purchasing the assets of the corporation which they desired to acquire, rather than the stock of the corporation. FTC, Sumiarary Report on tee Merger Movenent 1 (1948).

42. FTC, Sumiarary Report on the Merger Movement 22 (1948); Weston, op. cit. supra note 4 , at 15,30 (discussion and statistical analysis of the relative roles of internal and external expansion in industrial growth).

While absolute growth has resulted largely from internal expansion and merger activity within the past forty years has played only a minor role in effecting industrial centralization, the merger movement at the turn of the century resulted in a high degree of concentration in a large number of industries. And though subsequent growth has been predominantly internal, the relative positions of firms in these industries has resulted to a great degree from the original mergers. Id. at $48-49$.

43. See Machlup, The Political Econony of Monopoly c. 3 (1952); Stocking \& Watkins, Monopoly and Free Enterprise c. 3 (1951). 
within its relevant market.44 This measurement determines the degree to which the firm may control its own conduct and exact from the public undue entrepreneurial reward. ${ }^{45}$ And in a local market defined with respect to geography and product, there may exist many distinctly anti-competitive firms which have grown solely by internal means. ${ }^{46}$ Unlike externally developed corporations occupying a similar economic position, such firms would escape the reach of section 7 or any antitrust legislation cognizant only of merged interests. Pragmatically, the treatment received by each of two firms of equal size, market control and anti-competitive propensities would depend solely upon their formative history. The corporation becoming great through internal growth alone would be left untouched by a revision like that in $D u$ Pont, thus free to function as it had in the past. The corporation which developed in part from the union of pre-existing firms, on the other hand, would be open to judicial sanction up to and including divestiture and dissolution.

Such divergent treatment lacks suitable justification. Support cannot be premised on illegality of formation; the acquisition resulting in the firm's growth must have been legal when made or no need for judicial redefinition would exist.47 Similarly, the economic theories advanced in favor of the distinction seem, on the whole, unconvincing. They posit that internal expansion creates new productive facilities, thus increasing the flow of goods and com-

44. As the background against which the competitive effect of corporate activities are examined to determine whether an unreasonable restraint or a monopoly exists, the "market" is an integral part of antitrust thinking. It is defined both with respect to geographical area and product, the object being to locate the defendant within the area in which he competes. See Indiana Farmer's Guide Publishing Co. v. Prairie Farmer Publishing Co., 293 U.S. 268, 279 (1934) ; Standard Oil Co. v. United States, 221 U.S. 1, 61 (1911). For interesting and enlightening judicial treatments of market definition, see United States v. E. I. Du Pont De Nemours and Co., 351 U.S. 377, 393-404 (1956); United States v. Columbia Steel Co., 334 U.S. 495, 519-21 (1948); United States v. Aluminum Co., 148 F.2d 416, 424-26 (2d Cir. 1945).

45. See note 1 supra.

46. A significant number of extremely large national firms have grown with little or no external expansion. Weston, op. cit. supra note 4 , at $16,36,132-44$. While studies of industrial concentration have been limited to national firms, see note 4 supra, no reason appears for attributing to local firms an acquisition policy more active than that of the giant trusts, and it is probably safe to assume that local acquisition policy would be less active.

Section 7 of the Clayton Act will even be less effective in reaching the merged firm than would $\$ 1$ of the Sherman Act. For $\$ 7$ applies only to mergers effected subsequent to 1914. 38 Stat. 732 (1914), 15 U.S.C. \& 18 (1952); see note 24 supra. And the most significant merger activity occurred at the turn of the century, with many firms effecting no external acquisitions subsequent to their original formation through combination. WesToN, op. cit. supra note 4 , at 48-49, 136-49.

47. If illegal at consummation, the merger will of course fall within $\S 7$ as traditionally interpreted. See notes 17, 26, 34 supra. But see United States v. E. I. Du Pont De Nemours and Co., 77 Sup. Ct. 872, 892 n.14 (1957) (dissenting opinion) (section 7 may be inapplicable if the government has inordinately delayed suit). Or the merger might be attacked under $\S 1$ of the Sherman Act if it results in an actual restraint of trade. 
petition in the market, while external expansion reduces the number of firms and thereby decreases competition. ${ }^{48}$ In the short run, these propositions are unquestionably sound. However, they ignore the possibility that power internally gained may be incompatible with competition. ${ }^{49}$ Nor do they recognize that a merger may have been effected for purposes consistent with the aim of maintaining a competitive economy. A firm acquiring a dying competitor ${ }^{50}$ or two small firms merging to compete with larger firms in the industry constitute familiar examples. ${ }^{51}$ Since these theories would accord different treatment to firms equal in size and equally anti-competitive, they can at best be rationalized as justifying regulation of some corporations which unduly constrict competition. But if reform is to curb power, antitrust redefinition should seek out the existence of that power irrespective of the means by which it was attained. ${ }^{52}$

48. See, e.g., Zlinkoff \& Barnard, Mergers and the Anti-Trust Lawes: The Columbia Steel Case, The Supreme Court and a Competitive Economy 1947 Term, 97 U. PA. L. REv. 151, 173 (1948). The authors criticize the Court for implying in United States v. Columbia Steel Co., 334 U.S. 495, 532 (1948), that no distinction exists between the acquisition of existing facilities and the construction of new plants. They state that additional building increases goods and thus market competition, while absorbtion decreases competition. See also Bowman, Toward Less Monopoly, 101 U. PA. L. Rev. 577, 613, 631-41 (1953); Weston, op. cit. supra note 4, at 92-95 (1953).

49. See note 3 supra.

50. See International Shoe Co. v. FTC, 280 U.S. 291, 301-03 (1930); cf. United States v. Republic Steel Corp., 11 F. Supp. 117 (N.D. Ohio 1935). See also Donovan, Mergers and the Antitrust Lanes, 1 Antrtrust Butr. 179, 183-84 (1955) ; FTC, Report on CoRPORATE MERGERS AND AcQUISITIONS 10-14 (1955) (detailing economic forces and motives underlying acquisitions and mergers).

51. See Barnes, Economic Issues in the Regulation of Acquisitions and Mergers, 14 Onro St. L.J. 279, 291 (1953) ; Note, Section 7 of the Clayton Act: Problems Presented by the Automobile Mergers, 43 Gro. L.J. 634, 639 (1955); see also H.R. REP. No. 1191, S1st Cong., 1st Sess. 6-7 (1949).

52. Du Pont exemplifies recent judicial awareness of the need for expanded antitrust control. Doctrines such as "conscious parallelism" have been introduced to bring the Sherman Act more into line with industrial economic reality. See note 5 supra. That doctrine is not revolutionary. It merely makes parallel behavior an important element in proving the existence of the conspiracy or agreement required for a \& 1 violation. And circumstantial evidence has long been used as an element in proving conspiracy. See, e.g., United States v. Socony-Vacuum Oil Co., 310 U.S. 150, 223-24 (1940); Eastern States Retail Lumber Dealers' Ass'n v. United States, 234 U.S. 600, 612 (1914). But in placing increased emphasis on parallel behavior, rather than express agreement, the Court has started to make oligopoly behavior an element in Sherman Act enforcement. See Conant, Conscionsly Parallel Action in Restraint of Trade, 38 MrNn. L. Rev. 797, 821-23 (1954); Note, 54 Colurar. L. Rev. 1108, 1109-13 (1954).

The other principal doctrine enunciated to expand the Sherman Act is that of an "intraenterprise" conspiracy. Where a firm is composed of a number of independent corporate entities, courts have stated that the individual corporations are capable of conspiring among themselves for the purposes of $\S 1$. See Timken Roller Bearing Co. v. United States, 341 U.S. 593, 597-9S (1951) ; United States v. General Motors Corp., 121 F.2d 376, 404 (7th Cir. 1941). However, in the cases in which the doctrine has been enunciated there has existed an independent ground for finding antitrust illegality-either an illegal contract 
Although the alternative possibilities for judicial redefinition would give rise to uniform regulation of industrial concentration, reform, if any, should be effected in legislation. Power, whether internally or externally accumulated, could be curbed by reducing the judicially established definition of monopoly in section 2 of the Sherman Act or liberalizing the construction of contract, combination or conspiracy in section 1. The standards of section 2 could be lowered to include firms presently considered non-monopolistic, or under the contract, combination or conspiracy requirements of section 1 , "contract" might be defined as any contract made by a corporation, and "conspiracy," the joint action of corporate officers. Since a corporation cannot operate without making contracts or without officer co-operation, violation would follow whenever it grew to such proportions as to restrain trade unreasonably. ${ }^{53}$ Admittedly,

or an illegal combination. See McQuade, Conspiracy, Multicorporate Enterprises and Section 1 of the Sherman Act, 41 VA. L. Rev. 183 (1955) ; AtT'Y Gen. Rep. 35. Moreover, the policy of the doctrine appears to conflict with provisions of $\S 7$ of the Clayton Act which allow a corporation to cause "the formation of subsidiary corporations for the actual carrying on of their immediate lawful business, or the natural and legitimate branches or extensions thereof. ..." 64 STAT. 1126 (1950), 15 U.S.C. \& 18 (1952). A parent and its subsidiary may be expected to follow identical policies. Yet if such action can be the basis of conspiracy and ultimately Sherman Act illegality, the privilege granted by $\$ 7$ se'ems empty. See Note, 100 U. PA. L. REv. 1006, 1022 (1952). Finally, the effects of the doctrine can be avoided without the firm varying its over-all co-operative practices. It need only dissolve its corporate structure and organize along divisional structure lines to be free of any imputations of conspiracy. See Timken Roller Bearing Co. v. United States, 341 U.S. 593, 606 (1951) (dissenting opinion). But see note 53 infra.

53. The idea of inter-officer conspiracy is old in the law, and is a logical extension of intra-enterprise conspiracy. There is, in fact, some precedent for such a doctrine. See White Bear Theatre Corp. v. State Theatre Corp., 129 F.2d 600, 606 (8th Cir. 1942): Patterson v. United States, 222 Fed. 599, 619 (6th Cir. 1915). Although the doctrine has not been discussed by the Supreme Court, it has recently been strongly repudiated. See Nelson Radio \& Supply Co. v. Motorola, Inc., 200 F.2d 911 (5th Cir. 1952) ; Marion County Co-op. Ass'n v. Carnation Co., 114 F. Supp. 58 (W.D. Ark. 1953). See, generally, Comment, IntraEnterprise Conspiracy Under the Sherman Act, 63 Y ALE L.J. 372 (1954).

Alternatively, each contract made by a corporation which is in itself of such proportions as to be unreasonably in restraint of trade, would constitute a separate $\$ 1$ violation. Thus, in effect, the definition of contract and conspiracy made in text would operate to remove the multiple-party bar of $\S 1$, and make the test of legality solely unreasonable restraint of trade regardless of by whom and in what manner effected. Expansion of the term "combination" might not achieve this result. If combination is re-interpreted to mean a firm formed through union of existing corporations, maintaining its combination status throughout its existence, the objections of arbitrariness and incompleteness would apply. See notes 42-47 supra and accompanying text. For present interpretation of the term "combination," see note 13 supra. Yet to interpret combination so as to remove these objections by giving it the meaning of any union of persons or assets would directly con"flict with congressional intent as expressed through Senator Sherman on the floor of the Senate. See Letwin, Congress and the Sherman Antitrust Law: 1887-1890, 23 U. CHI. L. REv. 221, 252 (1956). However, since the multiple-party bar can be effectively removed through expansion of either the term contract or conspiracy, such redefinition is unnecessary.

The redefinition of "contract" and "conspiracy" would not affect the necessity for show- 
adopting either approach would entail evaluation and resolution of basic and coniflcting economic theories. ${ }^{54}$ Yet deciding which externally developed firms present the probability of unreasonable restraint of trade under the all-encompassing Du Pont redefinition of section 7 is not without problems. Moreover, any method of regulating economic power must encounter these basic difficulties of definition, and either redefinition would, in addition to curbing power, have the advantages of reaching all restraints and applying equally to all corporations. On the other hand, both constructions depart from the dual formulation of the Sherman Act. For redefining either section would render the other superfluous. ${ }^{\text {t5 }}$ Thus dependent on virtual repeal of the act, broad reform should

ing a restraint of trade. Extrapolating from the present law to a non-multiple party context, a corporation would violate $\$ 1$ whenever it controlled a percentage of the market sufficient to create a market effect equivalent to that heretofore considered an unreasonable restraint.

At present, certain practices, such as price fixing and territorial division, are per se violations. See note 2 supra. They are proscribed because of their inherent competitive effect. Agreement on price eliminates price competition. National Lead Co. v. FTC, 227 F.2d 825, \&33-34 (7th Cir. 1955), cert. granted, 351 U.S. 961 (1956), cert. denied to petitioner below, 351 U.S. 964 (1956). And territorial division eliminates a competitor from the market. See ATT'y GEN. REP. 26. But while such agreements are labeled per se offenses, the Court has placed the defendant within the relevant market, and found the wistcnce of these practices only where the defendant's acts have a significant effect upon that market as a whole. See Appalachian Coals, Inc. v. United States, 288 U.S. 344, 373 (1933) ; Board of Trade v. United States, 246 U.S. 231, 240 (1918). Violation of this per se test occurs only when the parties possess significant market power. Similarly, under the proposed redefinition of $\$ 1$, degree of market power would be determinative of illegality. The firm with little market power could pursue its normal practices without fear of $\S 1$. prosecution. The firm with a significant degree of power would clearly be subject to the proscriptions of $\$ 1$.

The theory underlying this standard conforms with existing antitrust philosophy, since the corporation would be examined in the context of its relevant market and the test of legality would be competitive effect. See notes 44-46 supra and accompanying text. Moreover, the standards so established are sufficiently flexible to allow the courts to examine thoroughly and evaluate realistically the degree of power possessed by a defendant firm. Only when its actions significantly affected the market, or unreasonably restrained trade, would a firm be considered to possess excess market power. And necessarily, the effect would depend upon both the percentage of market controlled and the structure of industry involved. In analyzing market effect, courts would consider, among other things, the industry's past operation, the market position of other firms, the level required for technological efficiency, ease of entry into the market, and, of course, the market position of the firm itself. See Adelman, Effective Competition and the Antitrust Laws, 61 Harv. L. Rev. 1289 (1948) ; Stocking, On the Concept of Workable Competition as an Antitrust Guide, 2 Antritust Bull. 3 (1956).

54. See notes 3,15 supra (collecting authorities).

55. The text assumes that the $\$ 2$ standard would be reduced to require at most an unreasonable restraint of trade. With both sections requiring the same standard-restraint of trade-\$ 2 would render $\$ 1$ superfluous. Section 2, in addition to proscribing multiple farty transgressions in like manner with $\S 1$, would also reach individual firm violations. Accordingly, no need for invoking $\$ 1$ would exist. This result would be exaggerated if $\$ 2$ werc reduced to require a lesser showing than unreasonable restraint.

On the other hand, if $\S 1$ were redefined, $\S 2$ would be of no additional value. Redefini- 
lie with the Congress rather than the Court. While the utility of instituting a reform enmeshed in fundamental difficulties of definition may be questionable, the undesirability of the $D u$ Pont redefinition seems inescapable.

tion of $\S 1$ would eliminate the multiple party requirement. See note 53 supra. Thus, a single firm could be successfully prosecuted when it acted in restraint of trade. In order to convict the same firm under $\$ 2$, the government would have to prove it monopolistic. Similarly, parties pursuing civil causes of action would have to establish either monopoly or restraint of trade. Since the individual firm could be reached without resort to $\S 2$, the lesser burden of $\S 1$ would be more attractive and hence more frequently sought. 